Oedipus before COVID-19 | 100

CÉSAR J. PÉREZ-LIZASUAIN ${ }^{1}$

\title{
Oedipus before COVID-19: An essay on the corporatization of political sovereignty and openings in the pandemic ${ }^{2}$
}

Alas, the pains I bear are numberless-my people now all sick with plague, our minds can find no weapons to serve as

our defense.

Our city dies-we've lost count of all the dead.

The Chorus in Oedipus Rex, Sophocles

-The calm has been felt.

-The tranquility is alive.

-Peace is ours.

-The country returns to normality.

-At six is the curfew.

-To protect citizen rights.

-The traitor is in jail.

-The one who tried to hijack power.

- Triumph of law, moderation, and order ${ }^{3}$.

\footnotetext{
${ }^{1}$ César J. Pérez Lizasuain is a sociologist of law, professor at the University of Puerto Rico in Río Piedras and author of the book "Rebelión, no-derecho y poder estudiantil: la huelga de 2010 en la Universidad de Puerto Rico" [Rebellion, Disorder and Student Power: The 2010 Strike at the University of Puerto Rico].

${ }^{2}$ This article was originally published in http://www.alternautas.net/blog/2021/7/7/oedipus-beforecovid-19-an-essay-on-the-corporatization-of-political-sovereignty-and-openings-in-the-pandemic

${ }^{3}$ Translated by the author. The original version is written in Spanish as follows: "-La calma se ha hecho sentir. -La tranquilidad está viva. -La paz es nuestra. -El país regresa a la normalidad. -A las seis es el toque de queda. -Para proteger los derechos ciudadanos. -En la cárcel está la traidora. -La que intentara secuestrar el poder. -Triunfo de la ley, la mesura y el orden".
} 
The Chorus in La pasión según Antígona Pérez, Luis Rafael Sánchez

\section{Thebes before the plague: the right of succession of sovereignty}

Just as in the tragedy of Oedipus, who witnessed his political power stagger due to the terrible plague which shook Thebes, the COVID-19 pandemic questions some of the tenets of political sovereignty and those who sustain it. This explains the diverse reaction of some international leaders when they attempt to frame the battle against the pandemic in terms of the nation-state: we are at war - we are told - against an invisible enemy. The chants of the ancien régime of sovereignty, that of the armies and the epic wars, attempt to cover up with absurd sounds something which they evidently cannot control by merely strengthening their borders or declaring war. In any case, in addition to the virus, it is the states which cannot contain the visible cracks of the capitalist world-system before the pandemic. In Thebes, the oracles alerted Oedipus about the origin of the plague: it was a curse caused by the unpunished crime provoked by the death of King Laius, the predecessor of Oedipus. Oedipus, witnessing how the plague-induced suffering threatened his position as sovereign, swore to himself that he would investigate, find out the whereabouts and identity of the murderer, and expel him from Thebes.

I was always attracted by the role of oracles in the story. I picture them as attorneys, in their offices and with enormous gowns. For whom can an oracle be an attorney? Does the all-powerful destiny require defenders? I think that the oracle, beyond the divine aura accompanying the title, is in truth a guardian; but not of kings or individual thrones or families or even the Law. The oracle is, in any case, a guardian watching after the preservation of the eternal order of sovereignty and the ruling class exerting it; a type of attorney for the right of succession of sovereignty, understood as a political, normative and class entity. As we know, Oedipus loses his place as sovereign when he discovers that the unpunished murderer is himself. But let us not fool ourselves with this tragic and predictable outcome, as in the end, the will of sovereignty is done: the person guilty for the murder of Laius was found, judged, sentenced and expelled from the kingdom. The circle is closed: sovereignty has prevailed, and the right of 
Oedipus before COVID-19 | 102

succession has done its job. We are back to normality: "Triunfo de la ley, la mesura y el orden" (The triumph of law, moderation, and order).

\section{The untold or unsaid dispositif}

\begin{abstract}
[...] the "perfect crime" does not consist in killing the victim or the witnesses (that adds new crimes to the first one and aggravates the difficulty of effacing everything), but rather in obtaining the silence of the witnesses, the deafness of the judges, and the inconsistency (insanity) of the testimony. You neutralize the addressor, the addressee, and the sense of the testimony; then everything is as if there were no referent (no damages).
\end{abstract}

The Differend: Phrases in Dispute, Jean-François Lyotard

In times when neoliberal reason prevails a large part of the world, systemic contradictions break out which, although previously existent, begin to appear without a façade due to the COVID-19 pandemic. Consequently, neoliberal sovereignty, in Puerto Rico as well as in the United States, has responded by telling us: salvation and responsibility for ending the virus is individual, wash your hands, forget public health expenses and social security, disregard the firing of nurses and doctors, let your old people die, ignore scientific knowledge and structural solutions, and focus on the corporative bailout to reopen the economy. In Puerto Rico, both the colonial as well as the imperial government, after Hurricane Maria and currently during the pandemic, have been determined to manipulate scientific and epidemiological knowledge to minimize the media impact that the number of victims would likely have on the collective psyche. A curious version of biopolitics. But as Michel Foucault stated, power apparatuses can have several forms: a law, an institution, a discourse, knowledge, etcetera. But he also stated that a power apparatus can be something "untold", a type of unsaid dispositif. How and why can an untold political relationship be articulated? 
The unsaid dispositif is not an isolated element. The untold is part of an apparatus combining practices and discourses which tries to legitimize precisely that which cannot be said. This is what we know: there are at least 4,645 deaths caused by Hurricane Maria which were not acknowledged by institutions. At this precise moment, we also know that diverse social sectors and scientists have warned about the dire lack of tests to diagnose COVID-19, and which should be administered both to the symptomatic as well as the asymptomatic population. We know that, without massive testing, epidemiological predictions are imprecise and significantly alter the perception of the current state of the rate of infection. The untold, that is to say, the systematic "invisibilization" of thousands of sick, discarded bodies as collateral damage, is accompanied by a discourse on "normality" which attempts to legitimize that the decisive criterion during the pandemic be circumscribed to an economic reason. It is not a coincidence that the Amazon behemoth is minimizing the amount of positive COVID-19 cases within its crowded warehouses. For example, as recently as February 12, 2021 the American newspaper The New York Times reported that the governor of the state of New York, Andrew M. Cuomo, is facing allegations that his government covered up the scope of the death toll in the state's nursing homes due to coronavirus.

This being the case both Puerto Rican institutions (or what remains of that) and Western governments in general, increasingly behave like Amazon. And this is the political crux of COVID-19: this time, the shock serves not just to advance neoliberal positions, as documented exhaustively by journalist Naomi Klein, but is rather a double assault: 1) By means of the culmination of the real subsumption of the government institutions and of scientific knowledge - such as medicine under the dictate of the economic reason or what we may characterize as a type of corporatization $^{4}$ or corporatized sovereignty; and 2) The unsaid also refers to the cultural and historical domains. It is therefore a robbery which attempts to reformulate and radicalize a subjectivity already provided by neoliberal reason by means of an operation which reinstalls a sort of social Darwinism; the economic man (homo economicus) is not just the subject of opportunities; he is also the most

\footnotetext{
${ }^{4}$ In this case, we may identify the corporatization of medical knowledge by means of an operation which reserves some of the elements of its early modern development, as described by Foucault: the current displacement of a social medicine in favor of an individualized medical practice.
} 
Oedipus before COVID-19 | 104

adapted (or resilient) to survive a scenario where both the state of exception and precariousness are constitutive of the normal situation.

\section{Kairos, post-pandemic openings and possibilities}

But we are not in a normal situation nor times. And "normality" as a discourse erupts as a device that intends to legitimize the prevailing social order prior the pandemic: that is the neoliberal normative order. Precariousness, austerity, and inequality seems all of the sudden desirable when Western governments and corporations lobby and call for "going back to normality" or "going back to work" without guarantees of any kind: by not providing the safety net of public health systems, or by not breaking the logic of patents that privatize medical knowledge and technologies (to that end, the $\operatorname{COVAX}^{5}$ initiative falls short ${ }^{6}$ ), or even by no guaranteeing free and accessible vaccination for all. But of course, yearning for this supposed return to normality precisely requires the legitimization of the current state of vulnerability caused by neoliberal policies (privatization of public assets, job insecurity, environmental extractivism, among others). Indeed, "normality" means the reestablishment of the state of exception.

But a question remains: Will we be the same at the end of the pandemic? Let's not be unwary, modern medicine (as a power device) was born in part due to a diversity of techniques and technologies that were put into practice during pandemics similar to COVID-19, significantly altering epistemic and cultural patterns of modern Western society. What, if any, will be the subject that emerges from this pandemic?

During the last year, many writings and analyses have circulated. Two of them are noteworthy: those written by Slavoj Žižek and Byung-Chul Han. The former understands the contradictions inherent to the capitalist world-system as open veins in the pandemic: the unsalvageable contradiction which exists between the capitalist political economy and life. Žižek portends, in this sense, that the virus

${ }^{5}$ COVAX stands for the "COVID-19 Vaccine Global Access Facility" supported by WHO and public-private partnerships. The initiative intends to coordinate the research, production, and distribution of COVID-19 vaccines around the world.

${ }^{6}$ See Santos Rutschman, A. (2021). The Intellectual Property of COVID-19. Forthcoming in Outsmarting Pandemics, Kirley E. \& Porter, D. (Eds.) (2021). Saint Louis University Legal Studies Research Paper Series 2020-28. 
reveals the ideological bias protecting capitalism and maintaining it as a hegemonic rationality. Given this situation, the Slovenian philosopher proposes a type of post-Soviet communism which protects the Common and which strengthens or reestablishes, as might be the case, public institutions in charge of remediating social inequality and administering the common good of collective corporal sanity: that is, public health. The second philosopher dares to portend an overturning of the current multipolar world in which the international eye will be fixed on Asia. Han maintains that Asia, after facing the pandemic with relative success, will offer what the rest of the Western world currently demands: greater safety and complex digital tracking systems. As Edward Snowden has recently warned, it would be a matter of accepting or even desire greater levels of mass surveillance, and of consenting to authoritarian practices executed by the bourgeois state.

Recently, a meme was circulating in social media in which the position of both philosophers was illustrated along with the following question: which of the two do you think is right? If I may be allowed to try an incomplete and generic answer: none. Placing both positions in a meme, one in front of the other, does not necessarily entail a dilemma which forces us to choose a side. The meme only expresses an opening. Both poles, contradictorily complementary, must be articulated to express a kairos: a moment of aperture in time, which itself alters the conjunction of present possibilities. Effectively, overcoming the pandemic necessarily requires articulating, from the here and now, inherently anti-capitalist practices which encourage cooperation and solidarity. For example, just as I write these lines, the government of Spain has approved a decree to make a Universal Basic Income (UBI) viable, while the government of Cuba sends a contingent of doctors to Italy. Both steps seek to face the contradictions inherent to a regime of inequality interposing corporate sovereignty of free market above life itself, and of millions of sick bodies. 
Oedipus before COVID-19 | 106

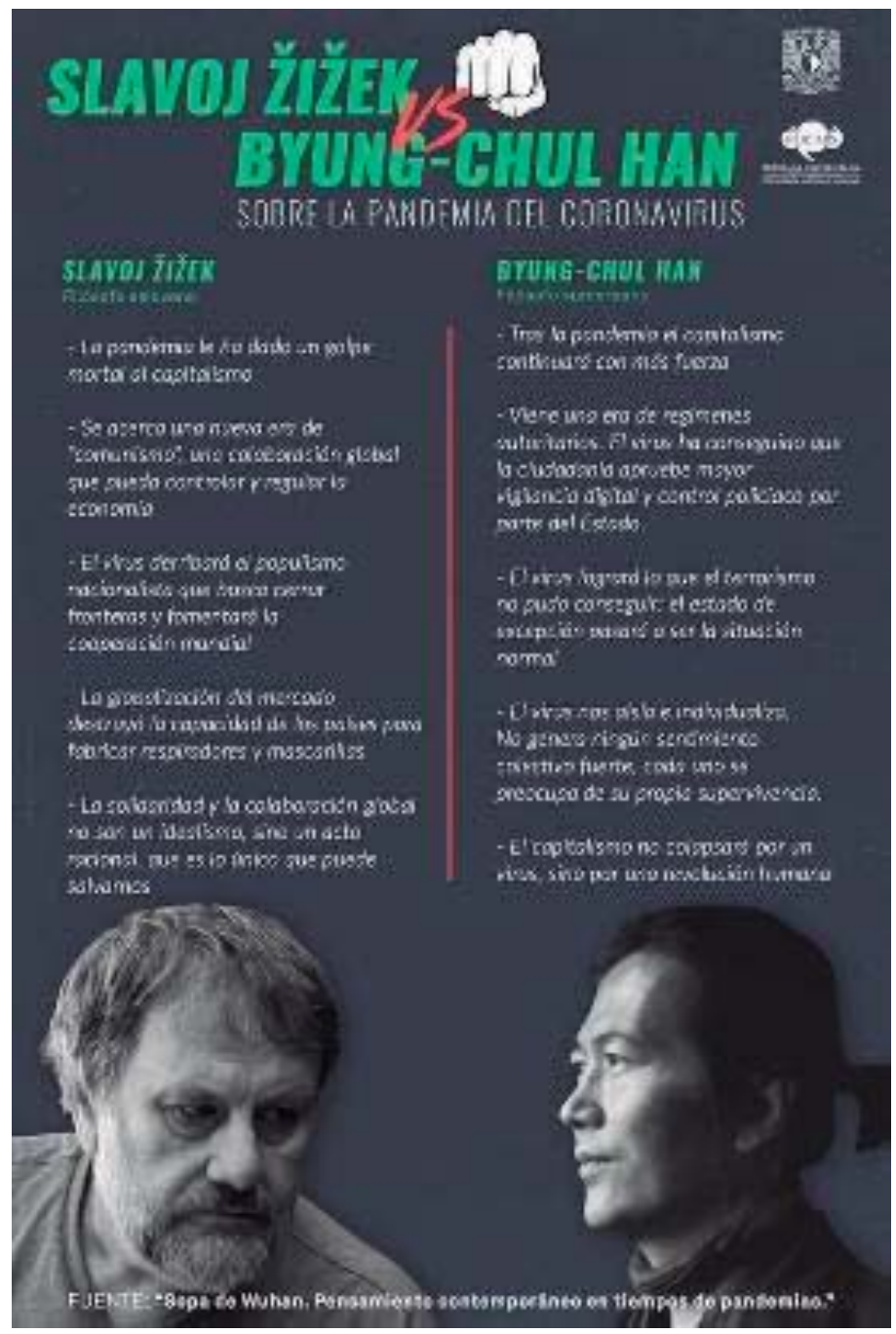

"The pandemic should shock people [...] to [the] recognition of the need to cure ailing societies of the neoliberal plague, then on to more radical reconstruction directed to the roots of contemporary disorder," suggests the good Chomsky. The problem with this statement is the focused on a deterministic premise: the "pandemic should shock people" as a moral cause with the effect of "recognition of the need to cure ailing societies of the neoliberal plague." Certainly, the virus does not lead us in a deterministic manner to cross the gap of a kairos which brings with it another complementary contradiction: rupture and creation. This risky gap, as rightly pointed out by Han, may only be crossed by means of the corporeal and 
passional action of the human being. Paraphrasing Alain Badiou in his book entitled The True Life: the moment we live in presents the prevailing need of changing the world, but that requires an explicit willingness to do it - that is to say, a subject of change (understanding that as the subject willing to explore the full possibility of a good life, common and collectively; to do so, risks must be taken (aka, revolution).

In this sense, we must surpass Oedipus and understand that the origin of the plague is not divine, but mundane; as mundane as COVID-19 itself. In any case, we must play the role of a rebellious Oedipus to renege with all our strengths the script which the oracle of corporate and neoliberal reason has in store for us: that is to break with the abstract suggestion, that unsaid dispositif, which attempts to present the very mundane sovereignty of commodity and capitalism as an eternal and inexhaustible order.

\section{References}

Agamben, G. (2009). What is an Apparatus? and Other Essays. Stanford University Press.

Badiou, A. (2017) The True Life. Cambridge: Polity Press.

Day, M. (2020, March 29) “Amazon Is a Breeding Ground” An Interview with Christian Smalls. Retrieved from Jacobin: https://jacobinmag.com/2020/03/amazon-warehouse-staten-island-strikecoronavirus

Emiliani, F., Contarello, A., Brondi, S., Palareti, L., Passini, S., \& Romaioli, D. (2020). Social Representations of "Normality": Everyday Life in Old and New Normalities with Covid-19. Papers on Social Representations, 29(2), 9-1.

Foucault, M. (1999). Estética, ética y hermenéutica. Barcelona: Ediciones Paidos.

Greenwald, G. (2020, April 8). Watch: Are We Vesting Too Much Power in Governments and Corporations in the Name of Covid-19? With Edward Snowden. Retrieved from The Intercept: https://theintercept.com/2020/04/08/watch-are-we-vesting-too-much-power-ingovernments-and-corporations-in-the-name-of-covid-19-with-edward-snowden/ 
Oedipus before COVID-19 | 108

Han, B. C. (2020, March 22). La emergencia viral y el mundo de mañana. Retrieved from El País: https:/elpais.com/ideas/2020-03-21/la-emergencia-viraly-el-mundo-de-manana-byung-chul-han-el-filosofo-surcoreano-que-piensadesde-berlin.html

Klein, N. (2007). The Shock Doctrine: The Rise of Disaster Capitalism. USA: Macmillan.

Lyotard, J. F. (1988). The differend. Phrases in dispute. University of Minnesota. Original: Le différend, Paris 1983.

McKinley, J. \& Ferré-Sadurní, L. (2021, February 12). New Allegations of CoverUp by Cuomo Over Nursing Home Virus Toll. Retrieved from The New York Times: $\quad$ https://www.nytimes.com/2021/02/12/nyregion/new-york-nursinghomes-cuomo.html

Polychroniou, C. (2020, April 16). Chomsky and pollin: To heal From COVID19, we must imagine a different world. Retrieved from Truthout: https://truthout.org/articles/chomsky-and-pollin-to-heal-from-covid-19-we-mustimagine-a-different-world/

Santos Rutschman, A. (2021). The Intellectual Property of COVID-19. Forthcoming in Outsmarting Pandemics, Kirley E. \& Porter, D. (Eds.) (2021). Saint Louis University Legal Studies Research Paper Series 2020-28.

Žižek, S. (2020). Communism or barbarism, as simple as that! In Pandemic!: COVID-19 Shakes the World (pp. 95-106). New York; London: OR Books. 